\title{
1 Introduction to a creative philosophy of anticipation
}

\author{
Jamie Brassett and John O'Reilly
}

\section{Opening gaps}

There were many anticipations creating this book. We start with the Second International Conference on Anticipation, held at Senate House in London 2017, where we (Jamie Brassett and John O'Reilly) organized and delivered a curated discussion panel - though this is by no means the earliest encounter germane to this story. Anticipation took the form of an atmosphere in this 1930s Art Deco building. Senate House was initiated by William Beveridge when he was elected to the post of Vice-Chancellor of the University of London in 1926. Beveridge's work anticipated and therefore created a new timeline of the future as the thinker of the welfare state that enabled heterogenous futures. Beveridge also had a different, more homogenous version of the future - like many of the pre-war left in Britain who were motivated by the idea of eugenics, the engineering out of undesired genetic qualities (Freedland, 2012; Renwick, 2019). For Beveridge, the anticipatory power of the welfare state gave way to the predictive power of eugenics.

The 19-floor building of Senate House was designed by vegetarian Quaker Charles Holden, a specialist in the atmosphere of the subterranean, having designed over 40 underground stations in London. The slightly dystopic atmosphere generated by the severe beauty of the building's Portland Stone materials haunted the future in the present in perfectly anticipatory fashion. George Orwell's Ministry of Truth in Nineteen Eighty-Four was modelled on Senate House. The strategy of organizational threat as a mode of political control by Orwell's Ministry of Truth, anticipates the operational logic behind the strategies of the US and UK governments nearly 20 years after the fictional year of the book - especially with the War on Terror. 'Fear is the anticipatory reality in the present of a threatening future,' writes Brian Massumi in his essay 'The future birth of the affective fact'. He continues: 'It is the felt reality of the nonexistent, loomingly present as the affective fact of the matter' (Massumi, 2010, p. 54). In everyday experience such prophecies can become self-fulfilling, but this disguises the affective, material power of threat as an atmosphere. The affective fact, Massumi argues, opens the way to generate and legitimate many different kinds of actions, actors and their networks to pre-empt the 
event they actualize as a threat. While Nineteen Eighty-Four is remembered as a future fiction of its written present experiences of totalitarian government, of systemic lying as a strategy, of war as a mode of being, it is a story about love and its anticipation; a story taken up by Jamie in his chapter.

There were other futures anticipated by Senate House; the most globally affective one is that of Gotham City. Batman Begins (Nolan, 2005) and The Dark Knight Rises (Nolan, 2012) make use of Senate House in their vision of Gotham. A city whose urban planning mostly consists of the creative act and atmosphere of chiaroscuro, from the bat signal to the shadows from which the hero emerges. Nolan's vision - about the breakdown of urban government, the anger of citizens finding expression in populist forms and autocracy - suggest perhaps that Senate House's architecture was in fact plagiarized from the future (as Derek Hales might say, in his pataphysical way, in this book's last chapter).

Our panel at Anticipation 2017 comprised four writers in this collection - Mark Donoghue, Anne Marchais-Roubelat, Fabrice Roubelat and John O'Reilly - with Jamie Brassett acting as chair. The panel also included Bettina Bouchayer who co-presented with Anne but who was unable to participate in this book. Its title, 'Inserting the Future in the Crannies of the Present', was a reference to a passage in philosopher, mathematician and physicist Alfred North Whitehead's Adventures of Ideas (1967b). In Chapter Twelve, titled 'Past, Present, Future', he writes: 'Immediate experience requires the insertion of the future in the crannies of the present' (Whitehead, 1967b, p. 191). What was most striking for us about this is the tone, its style. Its brash confidence disguises profound implications through a spatialization of time. Through this we become capable of acting on the demand of time; a demand that anticipates time because without this demand, this anticipation outside of time, there would be no time for time. Anticipation as the creation of time. (Both Marchais-Roubelat and O'Reilly deal with this.) Whitehead's phrase struck us as an important precursor to more contemporary accounts of anticipation (to which we will refer later in this book), where the future is not only met but brought into the present as a creative act.

If anticipation is understood this way, the novelty it creates cannot be predicted simply by adding the given components. The panel inserted the future in the crannies of the present by creatively substituting expectation with anticipation. Moreover, the passage from Whitehead resonated with our understanding and approach to design-intensive innovation (Lambert and Flood, 2018) and its management. We have wondered: if design contributes to, 'immediate existence' (or even wholly constructs it) then, at least, mapping and locating the possibilities for such existence to manifest itself is important act of creativity and futures thinking coming together (Brassett and O'Reilly, 2015, 2018a, b). Like this introduction, and the book itself, the mysterious landscape of the future described by Whitehead did not pre-fix the anticipations of the panellists. Whitehead's generous topography enabled different crevices to open in a specific present (that of a conference on anticipation), with creative potentials 
for our participants to fill. Mark brought the ontologies of the picture space into a mix with the ecological psychology of J.J. Gibson; Fabrice spoke through the divinations of Plutarch; Anne and Bettina presented Heidegger's conceptions of time in collision with specific forms of branding and marketing; and John the creative anticipation of Lucretius's clinamen in relation to the innovation of tennis players and Napoleon Dynamite (2004). Our then-present required us to find and fill some crannies in which to place various, unexhaustive and nontotalizing models of potential, possible, creative anticipation.

Here we are, some years later, having - at the very least - modelled various ways of working together: teaching, writing and practising. With that experience creating a space for diverse individuals and disciplines to collide and ricochet in many different directions. Furthermore, this experience has allowed us to develop a set of specific approaches to anticipation and the future which, while coalescing in a number of outcomes - the conference, this book, some journal articles and special issue editing - have refrained from homogenizing.

There is more. This book collects more than just those speakers from a specific panel at Anticipation 2 (2017). Some of our relationships are new to this book, others more long-standing. So here we have, in addition to those of us presenting in the Whiteheadian curated session at that conference: philosopher of the future and Ernst Bloch scholar, Nathaniel Barron; architect, philosopher, digital design expert and innovation practitioner Derek Hales (whose chapter here has links with his presentation at the first Anticipation conference at the University of Trento, Italy, 2015); social design expert and pioneer of policy-focused design innovation, Lucy Kimbell (who ran another panel at Anticipation 2, with the stand-up comedian Trevor Locke). All our contributors, their thoughts, practices and other creative moments entangle at various points and spin off away from each other at others - we will note some of these when we discuss the chapters in a little more detail below.

If we think of anticipation as an activity partly fostered by pressure from the future (thinking of anticipation also as an ecology of time) we might want to think again of atmosphere, but this time also in meteorological terms. In 'Affective Atmospheres', Ben Anderson (2009, p. 77) cites Marx's address to a gathering celebrating the fourth anniversary of the Peoples' Paper: 'the atmosphere in which we live weighs upon everyone with a 20,000-pound force, but do you feel it? No more than European society before 1848 felt the revolutionary atmosphere enveloping and pressing it from all sides' (Marx, 1978, p. 577). Atmospheres - even, or especially, those emanating from the future - argues Anderson, are produced by bodies (human, non-human, material, immaterial) but exceed them. There is something creative about the urge from the future that an atmosphere, felt as revolutionary, must exert on us. The atmospheres of this book began with the bodies of Senate House, our panel, the anticipation conference, meetings yet to come, all haunting of the future of this book - one time was anticipated in the moment of you reading this now. Other times got lost, haunting this book with other futures that may now be impossible. While another time had an atmosphere created by the bodies of COVID-19. 
But there is something that we need to note, to anticipate. For alongside the contextualization that we give of our completing the manuscript for this book as the time of the COVID-19 pandemic, another important event arose just before we submitted our manuscript: the killing of African American George Floyd by a white police officer. While the Black Lives Matter movement has been active for some years, and the issues it has coalesced around even longer, the protests and demonstrations galvanized throughout early 2020 by George Floyd's killing have forced many to reflect upon their privileges. And so, as we have arrived at the end of producing this book, we are deeply aware of the whiteness of the voices we have collected. This was never our goal and there are many reasons why this book has arrived in this condition, but no excuses. We offer the story here, therefore, not to excuse ourselves, rather as a cautionary tale.

From signed contract to required submission the process was particularly short, we felt we had no time to send out an open call for chapters, working with the group we had gathered around the Anticipation conferences. Beginning with an equal balance of gender positions the group was impacted by colleagues unable to participate, while others we approached found the time constraints too tight. We are sure that this book provides a set of creative perspectives on anticipation and futures studies that we feel is exciting, but we nevertheless recognize that we would have liked to have more scholars who identify as non-typical within our academic sectors, including people of colour. It should be noted that the scholars collected here exist at the intersection of a number of non-typical heritages, classes, socio-economic abilities and cultural positionalities: ours are not wholly and entirely privileged voices. Furthermore, we have - deliberately - engaged with scholarship and practices that are activist or non-typical. A few examples are: O'Reilly's examination of the activist, performative and theoretical work of Black Quantum Futurism and the Black Space Agency; Marchais-Roubelat's discussion of the poetry and religion of ancient indigenous people of northern Europe in relation to futurist approaches to organizational studies; Hales also encounters Afrofuturism alongside outsider theorists and practitioners; Kimbell's contextualization of her work in relation to age, gender, Alzheimer's disease and dementia. Notwithstanding this, we editors are cognizant of our product's partiality and that there are many other ways that our stories, concepts and practices could be told. We, Jamie and John, shall try to find the hope that is alive in the cracks and crannies of this work to create better futures; and therefore, to recombine new presents.

\section{Inserting futures (with a creative philosophy)}

Even in its recent development within futures studies, Anticipation has a recognizable characterization, which can be stated fairly simply: deceptively so. A system that anticipates is one that models a future, brings it into its present and bases decision-making upon this model. This modelling reorganizes the system and its present in such a way that one can say that the future is causing a present 
state. This is at the heart of key progenitor of these studies, Robert Rosen (1934-1998): a theoretical, relational biologist and mathematician. His most important work in this area is Anticipatory Systems: Philosophical, Mathematical and Methodological Foundations (2012; first published 1985) and, in it, he and colleagues attest to the difficulties wrought on his career as a scientist by propounding and sticking with something as so patently, apparently, ridiculous as the future causing the present. This is what you will see in any book on this topic, especially in its guise in futures studies - which is the context for this volume.

The other key figure in the development of anticipation studies is philosopher, futures scholar and thinker of complex systems, Roberto Poli. The scope of his work is astounding, which is manifest in his (2017) book, Introduction to Anticipation Studies. Poli is a figure with a significant presence in this volume, with explicit critical evaluations of his work in some chapters (Barron, Brassett, Brassett and O'Reilly, for example) and more lightly felt in others. Poli paves way for a philosophical approach to anticipation, which we follow in this book. His own philosophical interests and expertise, however, highlight some gaps in his mapping that we are pleased to explore given our various but aligning perspectives. Chief among these is the work of philosopher Gilles Deleuze, on his own and with his sometime co-writer psychoanalyst and political activist Félix Guattari. ${ }^{1}$ While Poli (2017, pp. 87-88) does make mention of Deleuze's philosophy - which comes as one of seven 'philosophical samples' (Poli, 2017, pp. 78-88) in Chapter 5 'Anticipation in Philosophy' - he is open about his own lack of acceptance of Deleuze's positions. It is interesting - stylistically and, maybe, psychoanalytically - that Poli's own voice is most personal and clear when writing of Deleuze. For example, he writes: 'According to Deleuze, this virtual form of causation is categorically different from ordinary mechanical causation. I have to admit I fail to see why' (Poli, 2017, p. 88; emphasis added). Now, of course, there is nothing at all wrong with such a statement; but, in this volume, there are many of us who seek to investigate aspects of Deleuze's - and Deleuze and Guattari's - philosophies that we find do offer insights into futures in general and anticipation studies in particular. This is not to say that Poli is therefore wrong in his analyses. Our approach is more open than that (and Brassett may say, in the terms put into play by his chapter in this volume, "sympathetic'), an approach itself influenced by an insight from Deleuze (1995). In a 1986 interview about Foucault's work - just two years after Foucault's death and at the time that Deleuze (1988; originally 1986) published his book on his friend, titled simply, Foucault - titled 'Breaking Things Open, Breaking Words Open' (pp. 83-93), Deleuze (1995, p. 87) says this: 'Never interpret; experience, experiment'. The urge not to interpret allows different interpretations to live together, for when the judgements it requires are not the most important act to deliver, then multiple interpretations can abound. That no one should be getting philosophically extremist about canon, is a valuable take away we have from the philosophies (and other attitudes: literature, psychoanalysis, politics, for example) that Deleuze and Guattari create. 
This leaves us with, 'experience, experiment' - on which the translator's note says: 'The single French verb expérimenter means at once to experience, and to experiment' (Deleuze, 1995, p. 197, n. 13). This provides a different attitude to philosophy than the interpretative. Ours is a philosophy of making, doing, creating, living and is found joyfully expressed from Deleuze's early work on Spinoza (1990b; originally published 1968) and Nietzsche (1983; originally published 1962) to the collaborations with Guattari (1984, 1988, 1994). Philosophy makes, does things with the concepts it encounters and experiences. It experiments; it creates. This is carried even further in Deleuze and Guattari's last book together, What is Philosophy? (1994; originally published 1991) where they argue that philosophy can be characterized by its powers of concept creation. Thus, an important aspect of anticipation - that a model of the future is used to recreate the present - is also an aspect of philosophy as we will be using it. This allows us to follow a tributary from the style of philosophy that Poli produces to another, one different to his, which - it is our hope - will offer something else in addition. Important here is the philosopher, scientist and philosopher of science Isabelle Stengers, for whom Deleuze and Guattari's works are influential. In an essay on What is Philosophy? Stengers (2005, p. 152) writes the following:

It is his [Deleuze's] one book that addresses its reader as if he were perhaps a friend, but at that twilight hour 'when one distrusts even the friend,' even the one who had most enthusiastically followed the great opening of possibilities that Deleuzian themes have inspired. Here, the crucial problem may well be that 'we lack resistance to the present,' [Deleuze and Guattari, 1994, p. 108] and to resist here does not mean to criticize or to denounce but to construct.

This is a passage that gestures towards Nietzsche in a way that we will in the chapter that follows this introduction, with further concepts taken up more fully in Brassett's chapter. Still, for now, our own 'resistance' to Poli's review of Deleuze's work is a thoroughly constructive one. The passage from which Stengers quotes about resistance to the present is worth citing in full. Deleuze and Guattari (1994, p. 108) write:

we do not lack communication. On the contrary, we have too much of it. We lack creation. We lack resistance to the present. The creation of concepts in itself calls for a future form, for a new earth and a people yet to come. (Original emphasis.)

When resistance is creation, 'resisting with concepts' can be another way of saying 'philosophy'; a philosophy that calls for a 'people yet to come' to come. A future can only be made to come here, to the present, if we open ourselves to the possibilities that we, here, now, our 'immediate existence', may be recreated by the arrival of the 'people yet to come'. Stengers is surely one who has 
been a sympathetic friend of the ontological reconstruction on offer in Deleuze and Guattari's work; she may even be the friend 'who had most enthusiastically followed the great opening of possibilities that Deleuzian themes have inspired' now distrusted or, at least, resisted. Indeed, their phrase 'a free and wild creation of concepts' - characteristic for them of 'English Philosophy' (Deleuze and Guattari, 1994, p. 105) - ends up as a subtitle of her Thinking with Whitehead. A Free and Wild Creation of Concepts (2011; originally published 2002).

Stengers's philosophy is an adventure, an exploratory and experiential voyage into the future in a way that brings the future back to hand. She writes, in an article on Whitehead's 1927-28 work Process and Philosophy:

The adventure of the creation of a conceptual agency cannot be disentangled from the experiential adventure of the philosopher experimenting disclosure. We can speak here of 'experimenting' because the disclosure is part of a process that can be described as conceptually 'lured'. Each concept has to be designed and redesigned, as the point is not of adequacy to some kind of pre-existent matter of fact but, rather, that of two questions which are always at work together: is the conceptual agency succeeding in doing what the philosopher wants it to do, and are those aims an adequate expression of the challenge she has decided to confront?

(Stengers, 2008, p. 97)

We can say that, in anticipation, a future is 'lured' to the present; with 'lure' in Stengers's sense to work utterly in registers of adventure, speculation and experimentation. She writes: 'For the value of concepts is to lure new feelings, to induce "sheer disclosure" as a new way for experience to come to matter' (Stengers, 2008, p. 100). A lure is modelled on a future state where a thing to be caught will find it attractive and bites. If a concept is to 'lure' it is to be launched into all our presents as a future possibility that, once allowed in, can recreate experience, or even modify existence. It will be an adventure and an experiment; it will speculate and allure; it will resist and create. We return to Whitehead's (1967b, p. 191), '[i]mmediate existence requires the insertion of the future in the crannies of the present'. This points in another, ontological, direction that is of importance to us in this book. ${ }^{2}$ Before we come to that, there is a little more to say about types of creativity.

Up till now we have directed our attention to two important pillars of this volume: philosophy and creativity; both of which have valuable links to anticipation, as well as with each other. Many of us in this volume have some sort of relationship to the creative industries and education (which often now coalesce as both creativity and education - along with government become business as a function of neoliberalism. From a design perspective see: Julier, 2017). And at one point 'design' was going to be another pillar of this book. Indeed, some of us here refer to particular design practices (for example: Kimbell on textiles, printmaking and design fictions; Hales on architecture and speculative design; O'Reilly on design-intensive innovation education; 
and Barron on design philosophy). The trajectories that each chapter takes, however, tend to accentuate the philosophical and creative, rather than a commonly discussed and recognized creative practice: like design. (Though, even to describe design as a 'recognized creative practice' is to stretch facts a little too far, as its ever-changing multiplicity is seen as problematic by some (Verganti, 2009) or a benefit (Brassett, 2015).) However, we do not provide a sustained interrogation of 'design' for it to warrant an important place as a focus for this book. Along with some exemplifications of our own conceptual experimenting of anticipation through design (as mentioned just above), we do refer to other forms of creative practice: textile design and painting (Kimbell, Donoghue); organizational design and design thinking as a business practice (Marchais-Roubelat, O'Reilly, Roubelat); literature (MarchaisRoubelat, Hales, Brassett); and, even, science (Brassett, Donoghue). So, the role of various creative practices is important here, too. Before positioning the chapters in more detail - but with greater emphasis on where some ideas put forward might lead - we will say a little more about a final, crucial aspect of this book.

As we parse a number of creative practices from a focus upon creativity, so do we highlight a particular aspect of philosophy: ontology - the philosophical questioning of being, often thought of as the asking and attempt at answering the question, 'why is there something rather than nothing?' Once again, we are guided here by Poli, who has specific articles on this (Poli, 2010a, 2011; Poli and Seibt, 2010) and who notes in Chapter 7, 'Ontological Sketches' of his Introduction to Anticipation Studies (2017, p. 103) that 'ontology is the theory of entities and their structures' that often involves, formally, 'dealing with categories like thing, process, matter, form, whole, part, and number' (Poli, 2017, p. 102; original emphases). We will not be arguing about ontology from first principles, however, neither will we attempt to establish categories as those Poli mentions just above. We will be working with (experimenting and experiencing) these ontological categories in the company of some philosophers who have developed key approaches to these (and more). You will find us discussing 'thing' with Latour (2008) or 'process' with Whitehead (1978), 'wholes' and 'parts' with Stengers (1997) or time with Heidegger (2007), many of which fold back and through the works of Deleuze and Guattari. Oftentimes, Poli examines these ontologies and categories through the works of Edmund Husserl (1859-1938), Nicolai Hartmann (1882-1950) and Ernst Bloch (18851977). Such, respectively, phenomenologist, critical realist and Marxist critical theorist approaches take different directions from those we present here. Except for one: Nathaniel Barron. A Bloch scholar, he provides a critique of Poli's approach to Bloch that allows him (Barron) to develop some important conclusions about the relationships between anticipation, ontology and creativity. For Barron, Poli is closer to Adorno (or even Kant) than Bloch, even while Bloch plays an important part in his (Poli's) philosophy of anticipation. Barron states it is important that 'if anticipation studies is concerned with the ontological reason for anticipation's existence, then it should also understand 
that that reason involves the question of goal' (personal communication, with permission).

But we are running ahead of ourselves a little. Here are the main points to take, then: that our interaction with anticipation will be largely philosophical and then with a great focus upon ontology; we will use these to focus upon the conceptualization of creativity and its role in anticipation. Now we move to the chapters a little more closely.

\section{Anticipating chapters}

The framing and situating remarks for this book are done with and we will next look over the chapters themselves. Traditionally, editors would be expected to provide some summary of the individual chapters. We will do this minimally, as we are seeking neither to interpret nor to overpower our readers' own interpretative flourishes. Here we devote more space to following 'lines of escape/ flight' (Deleuze and Guattari, 1984, 1988) from these chapters in directions that are variously suggested to us, especially insofar as they approach issues of creative practice. To do this is to pick up some key concepts and run with them to see where they take us; to launch them into new areas and see what splashes they make; to insert them as cogs in different machines to see what is produced.

The discourse of the 'spoiler' in cinema is pertinent here: to spoil the plot, the narrative, the ending for those who have yet to see the film by those who have. Might this introduction be to the book what spoilers are to films: telling the reader what is to come, anticipating the readers' reading, predicting and thereby owning the 'best bits' for the reader - we will come back to this notion of 'best' later. Corporate futurism is often, literally, spoiling. The future as the site of corporate concerns does not necessarily align with that characterized by the concerns of people in the future to come. Although such scenarios make it so, make people subject to corporate concerns. The originary myth of Shell's scenario planning in the 1970s may have been wrapped up in the need to avoid another energy crisis, but they did not see the ecological catastrophe of the future-present they were creating.

We are not looking to spoil, though. Our recasting of this book's origins we present as a tale of chances rather than one of authenticity. And our mapping of the chapters we hope is more to do with seeing what, else, might be of interest. In a way, each of the paragraphs below that discuss the chapters could be read immediately after the chapters themselves; maybe you can try it and head straight in now? This might allow us past any accusation of spoiling. But now, the chapters.

The nine chapters that follow in this book share concerns with anticipation, creativity and philosophy, however each paper anticipates the concept with a style of research that affirms its disciplinary concern with anticipation but also anticipates the novelty of anticipating with creativity and with the future of a discipline different, even while they align at moments. 


\section{Picturing}

Mark Donoghue's chapter 'Anticipation, creativity and picture perception' has developed from research he has been carrying out on the ontology of picture spaces, with reference to the works of Deleuze, nineteenth-century Japanese artist Katsushika Hokusai (1760-1849) and ecological psychologist James Gibson (1904-1979). His chapter here focuses upon the logics of perception and the anticipatory ontology of picture spaces. In order to do this, Donoghue brings the philosophies of Henri Bergson (1859-1941) and William James (1842-1910) - especially their concepts of duration (la durée) and Pragmatism respectively - into collision with concepts from the Bayesian theory of probability. This, Donoghue readily recognizes, may seem like a paradoxical collection of concepts to bring together; that is, to imagine processes of prediction in relation to those of generation of novelty. He shows these paradoxes permeating both Bergson's and James's works and it is through their evaluation that Donoghue can begin to outline a future- and present-focused creativity. Thus, creativity is that which exceeds normal psychoneurological processes of probability calculation and predictive patterning, even while it finds a ground there. This provides Donoghue a position that not only develops from Bergson and James's philosophies, but also brings it into proximity to the work of Deleuze; particularly Deleuze's (1990a) The Logic of Sense, in the fifteenth chapter, 'Of Singularities' (pp. 117-125), where Deleuze navigates the different generating processes of persons, individuals, events and, of course, singularities. One of Deleuze's concerns here is in the energetic modifications and modulations of the ontological process of becoming and, at one moment, he quotes philosopher of technicity, Gilbert Simondon (1924-1989) thus: 'The living lives at the limit of itself, on its limit' ( Simondon, 1964, p. 260; quoted in Deleuze, $1990 \mathrm{a}$, p. 119). To live at the limit is to experience the limit and to experiment with exceeding it; it is to spread outwards from a ground to (and over) the edges of experience. An ambitious piece of work, this chapter manages to engage our shared subject with a transdisciplinary and creative flair. We wonder how the arguments Donoghue gives here might fare in relation to the speculative and process philosophy of Alfred North Whitehead (who was well disposed to both James and Bergson), as well as the evolutionary biologist and philosopher C. Lloyd Morgan (whose work on Emergent Evolution (1927) dealt positively with James, Bergson and Whitehead). To recognize creativity as that which outpaces any simplistic analysis of parts in a reductive manner, aligns with the various positions we shall adopt throughout this book: particularly those on anticipation.

\section{Runes}

Anne Marchais-Roubelat's chapter, 'Flowing or frozen anticipation? Runes and the creativity of time', brings to anticipation a critique of time in futures studies from the perspective of Heidegger's concepts of frozen and flowing time. Rich in reference to research in organization studies, Marchais-Roubelat 
also works her argument in relation to Old Norse poetry and Anglo-Saxon runes. If, she argues, the creativity alive in anticipation accesses time thought as fluid, complex and nontotalizing - as another option to time regarded as frozen, instrumental and measured - then an anticipatory organization should be able to loosen its rigid ontology and so find an attitude to uncertainty that is less terrifying and more fruitful. This aligns, we think, with the creative ontologies of innovation management and organization theory found, especially, in the work of Haridimos Tsoukas and Robert Chia (Tsoukas, 1998; Chia, 1999; Tsoukas and Chia, 2002) in particular and in Process Organization more generally (for example, Hernes, 2014). Yet Marchais-Roubelat's chapter heads in the most creative directions by engaging with runes, discussing their multiple nature of divination, magic and narrative production; and, even further, in regarding runes as event. This requires us to encounter the temporalities of magic, divination (Marenko, 2014, 2015) and a narrative production that weaves them all simultaneously, heterogenously, in their full complexity and creativity. This is an ambitious argument and provides avenues for future research that are rich in their possibilities. We would be particularly interested to see where anticipation as event might lead us, following MarchaisRoubelat's insight into the divinatory power of runes as events. This would manifest also an encounter with Whitehead, especially through his conception of the 'event'; and, indeed, Deleuze's (1993, pp. 76-82) relating of this to Leibniz. Events have 'actions, effects and influence', do not have a sense of their own 'function' and become problematized by their relationship both to singularities (see: Deleuze, 1990a) to endurance (see: Stengers, 2011, pp. 185200; also, Donoghue in this volume, in relation to Bergson's notion of 'duration'). Stengers is clear about Whitehead's atomism, especially as expressed in relation to his ontology of events. She quotes (Stengers, 2012, p. 188) from his Science and the Modern World (Whitehead, 1967a, p. 103) thus: 'We must start with the event as the ultimate unit of natural occurrence. An event has to do with all that there is, and in particular with all other events.' These are exciting times for an adventure into anticipation, as Stengers might say; and MarchaisRoubelat plays a part in taking us there.

\section{Hope}

Nathaniel Barron's chapter, 'Ernst Bloch's ontology of not-yet being: Intuiting the possibility of anticipation's fulfilment', is a closely argued interrogation of the ontology of hope that Bloch (2000) develops. Barron situates his examination in terms of developing a philosophy of design that, for him, has been lacking a thorough engagement with Bloch, one of the twentieth century's most accomplished philosophers of hope. Barron has a point. There is a phrase from the 1978 Nobel Laureate in Economics, Herbert Simon (1988, p. 67), which has become canon in design research: 'Everyone designs who devises courses of action aimed at changing existing situations into preferred ones' (emphasis added). Simon enhances the teleological attitude further: 'Design, on the other 


\section{Jamie Brassett and John O'Reilly}

hand, is concerned with how things ought to be to be, with devising artifacts to attain goals' (Simon, 1988, p. 69; emphasis added). Simon's approach was influenced by his trust in methods and logics from the 'hard sciences' and the training he had in both the 'Chicago School' of economics and political science and as a consultant at the RAND Corporation (1951-76) (Huppatz, 2015; see also Bousbaci, 2008). Simon's centrality to the expression of design as a science is without question, but for those of us with perspectives on design infused with qualitative, nonlinear, emotional or artful energies, Simon's approach is limited (Celi and Morrison, 2017). It is notable that 'rational choice' in economics (Kay, 2013; Goodwin, 2014), 'mutually assured destruction' in military-political strategy (DeLanda, 1991) and a fact-oriented scientificity for design (Latour, 2008) have, since the 1990s, variously made way for more complex and qualitative approaches to their subjects, and more. The disruption that Barron offers, with Bloch's help, to the type of logical design Simon promotes, is one that highlights the philosophical, political and ethical power that are intimated by Simon's 'ought' and 'preferred'. Barron's is an ethics instantiated by the focus upon the action of self-developing self-critique: an ontological exposition of the ways and means that we may be. While Bloch's work is remembered more for its phenomenological and political power than its ethics, when Barron's Bloch comes towards creative practice such ethics (along with politics and ontologies of course) are foregrounded. For Barron, this is an approach that is activated by Bloch's insight (1985, p. 147) into the 'darkness of the just-lived moment' (Barron's translation). This Barron works through the concept of what he calls Bloch's ontology of 'not-yet being'. That there is a need for being to be future oriented is attested to by both its inability to find an existence that can be consummated fully in the present and an emotional charge around this inability that manifests as this 'darkness of the just-lived moment'. This is an extremely important issue for Barron, leading him to stress its ramifications as an imperative: anticipation must take seriously Bloch's insight that a not-yet being has potential for future actualization, for its (anticipation's) ontological promise to be fulfilled. Bloch and Barron provide another angle on the contemporary's perspective on present darkness that Brassett and O'Reilly develop in Chapter 10; and the hope, the light in the darkness, however minuscule, that lures anticipation on its creative journey. (Barron does this in relation to a critique of Poli's readings of Bloch, which we have already intimated. We will leave this for you to discover.) For us, this takes Bloch away from a recognizable - and maybe simplistic - dialectical motor where negation (a lack) is resolved through synthesis with what was negated. Both the untimely and the contemporary do not negate, theirs is not a nihilist moment but a creative one: the future alive in anticipation is that the not-yet is also a becoming. (This becoming, this ongoing transformation of existence into something more, something exceeding itself, is apparent not only here but in the next chapter too.) Barron positions Bloch's work within the anticipatory context of 'utopia', re-reading the history of philosophy and in particular concepts of 'creativity' and 'causality', in terms of anticipation. 
The problem of anticipating a future creatively, argues Barron, is always one of an incapacity for 'beginnings'. Unfortunately, the art of revealing possibilities for renewal is all too often rendered insensible to us by powers which seek to perpetuate an idea of the eternality of the content of the present. It is capitalism's blind spot that Barron teases out: the invisible sensible. Indeed we might argue that it is this blind spot which disables neoliberal capital to see an 'outside' future, a utopos, that could predict anything other than 'neoliberalism $2.0^{\prime}$ as the future of algorithms that talk to each other - smart cities, big data healthcare, driverless cars - because they already know who we are and what we will become. We wonder whether sensible presentation of Utopia is possible in forms of foresight delivered as scenarios and PowerPoint presentations; or whether the blind spot of corporate futurism lies in the digital imagination of Redmond and Cupertino.

\section{Rules}

In 'Are scenarios creative? Questioning movement and innovation in anticipation practices', Fabrice Roubelat uses his expertise in scenario planning - as a scholar and practitioner - to engage anticipation and creativity to imagine innovation differently. By developing an argument around the value of movement and action in futures thinking and practice, he cautions scenario designers not to think that their creative products are immutable and always relevant; similar to the famous line from Prussian field marshal Helmuth von Moltke (1800-1891) - that no plan survives the first encounter with the enemy. Roubelat's position aligns with a tendency in innovation management studies over the last 25-30 years or so that values a lithe and dynamic approach to organizational design, strategy and market orientation: notably the 'ambidextrous organization' (Tushman and O'Reilly, 1996); process ontologies (Tsoukas, 1998; Chia, 1999; Tsoukas and Chia, 2002; Hernes, 2014) and complexity (Brassett, 2015); but also, more recent trends in design thinking (two of the most influential texts are: Brown, 2009; Martin, 2009). But Roubelat is able to bring together thinking from Platonist philosopher Plutarch, philosopher of science Thomas Kuhn and scenario developer Herman Kahn (among others) in developing his perspective. Yet, this chapter is not as straightforward as it may seem, for Roubelat finds that his proposition of 'moving scenarios' shows that Kuhn's conception of scientific paradigms is not as robust as its reputation. The relation between a set of dynamic and complex scenarios and the rule-sets, practices and interests that manifest it provides a landscape that is neither as homogenous nor as recognizable as a paradigm. This is exacerbated even further, when we consider the push for a 'decolonized' account of the power of scientific relationality of the type advocated by, for example, philosopher of science Arun Bala (2006). The complex topology of interconnected, dialogic communities around the globe, now and throughout history, provides a space for thinking scenarios in a much less simplistic way. Even more, Roubelat's positioning of Anticipation is not so 
supportive as that of many of us in this volume: he is wary (rightly so in our opinion) of its teleological nature, but still finds useful its imaginative tendencies. So, while some of us have excitedly embraced the novelty of the practice of anticipation in relation to futures studies, Roubelat's steady location of it within a fairly well-recognized futures process as scenario design is a welcome critical contextualization.

\section{Stitching}

John O'Reilly's chapter is concerned with practice and its manifestations across research practice, creative practice, philosophical practice and pedagogical practice. These are situated between two separate events: NASA's development of the spacesuit for astronauts in the late 1950s and early 1960s and the instantiation of Black Quantum Futurism in 2015. Both involve obfuscated, obliviated or simply minoritarian discourses and practices in creative product development and creative activism. Encountering innovation processes, structures and deployments of power/knowledge and creative ontologies of anticipation, O'Reilly makes a case for the courage it takes to think and act otherwise than normal. To do this he highlights an observation by Argentinian Walter Miller, who has spent the last 30 years exploring ways to unpick the modern/colonial system and develop a thinking and politics of justice. In Miller's book (2011) The Darker Side of Western Modernity: Global Futures, Decolonial Options, he writes that: 'The illusion that Western Civilization could create the problem and solve it is facing its limits' (Miller, 2011, p. 282). It is a hopeful thought, though it will not be easy, because as Malcolm McLaren, innovation manager of Punk, realized ('quoting' the Situationists): 'capitalism sells our boredom back to us'. The capitalism engendered in the west (though currently with many characteristics) is particularly adept at folding its edgy and possibly destructive - outsides back into the middle to energize its own creative approaches to surplus value production. A monomaniacal monopolization of capital will simply increase entropy unless the system is opened to the creative outsides (Serres, 1982). Deleuze and Guattari $(1984,1988)$ call this 'schizophrenization'. Just as the oil companies broke the planet notwithstanding their scenario and foresight work (however far they thought the unthinkable), there are corporations willing to capitalize our futures and sell them back to us through the micro targeting offered by abilities to manage large data sets. This 'corporate imagination' controls the intellectual, political and commercial currency of the future unless we can think and act otherwise, 'other-wise' as O’Reilly puts it. He writes:

In the terms of this chapter, we might say that anticipation - as a form of creative researching - is also the capacity to anticipate beyond the given discourses of needs. Anticipation as research is always excessive. In exceeding and overflowing the given epistemologies the hyphen of the Otherwise is an artefact created by our research, and this hyphen which connects 
and separates, begins to anticipate the kind of discipline anticipation might need to engage with if it is to stay open to the Otherness of the future.

As well as the 'others' in the present.

\section{Love}

Jamie Brassett uses the creative ontologies of anticipation, in the interleaving contexts of love and friendship, to drive a critique of the future's collusion with war. His chapter 'For a creative ontology of the future: an ode to love' interrogates Robert Rosen's speculative, relational biology in conjunction with Roman poet, scientist and philosopher Lucretius's creative atomist ontology. For Lucretius (2007), life is a materialization of love and for Rosen (1991, 2000, 2012) anticipation is one of the key characteristics of life. Why, Brassett contends, is much forward planning infused with strategy, a term of war? Lucretius, on the other hand, looks to the creative, generative power of love. And philosopher Michel Serres (1977), in his critical evaluation of Lucretius's work as a forerunner of more contemporary nondeterministic dynamics and negentropic complexity, argues the same. The concern then becomes: how might future-oriented work characterize itself in relation to love not war? Serres and Lucretius provide a way out of the foedus fati, the atomic fall to death in which strategy is implicated, through the foedera naturae, the natural treaties of a swerved, local, relational, creative universe. For Brassett, this is delivered - at least partially - through anticipation and the relational ontologies it articulates, both at its origin and in its contemporary possibilities. The sense of life, creative and loving, that we find in Lucretius encounters Rosen's relational biology of life: one that is always overflowing and exceeding the basic elements to which much contemporary physics seeks to reduce it. Serres is particularly vehement in locating identity and homogeneity with death and entropic stagnation; we might also require similar in ensuring anticipation (as an act and a developing disciplinary studies) a creative, loving future.

\section{Emission}

Lucy Kimbell manages to embody many different kinds of expertise: designer, artist, Science and Technology Studies scholar, social design expert and one of today's key developers of designing for policy. Kimbell brings both a highly affective perspective and rigorously argued examination of the ways in which an anticipatory art and design can be thought and practised. Her chapter, 'Inventive devices and public issues: The Air Pollution Toile', centres on her speculatively designed wallpaper toile that is simultaneously haunting and provocative. With patterns that change in relation to the various particulates of our polluted, metropolitan living, Kimbell's wallpaper locates itself within those design and design studies traditions that deliver both critical commentary on contemporary concerns and speculative accounts of possible action 
(for example: Dunne and Raby, 2013; Yelavich and Adams, 2014). Kimbell weaves the manifold pragmatics and critiques of her positioning into a text shot through with capacities for affecting and being affected that are crucial components of any relational ontology. While Kimbell's focus is turned elsewhere, with this mention of 'relational ontology' we (Jamie and John) see the relationality of the theoretical biology of Robert Rosen (who, as noted already, is a key figure in anticipation studies), as well as a brief mention of his tutor and mentor, Nicolas Rashevsky (1899-1972) who coined the term 'relational biology' and from whom Rosen took up the antireductionist cause (Nadin, 2010, 2011). It is worth noting here, briefly, that a relational ontology also suffuses the metaphysics and ethics of Baruch Spinoza (1996). We have investigated the ways in which Spinoza's ontology might be brought to futures and design (Brassett and O'Reilly, 2015; Brassett, 2016), ethics and social design (Brassett, 2018). We wonder, here, how these modes of thought may extend from and into Kimbell's toile. An intriguing aspect of Spinoza's ethics, especially for those of us involved in design and the arts is the dissolution of a body from a bounded entity to one that is predicated on its relations; those articulated as affecting and being affected. It is clear, for us, that Kimbell's toile is expressed both as a set of relations - pollution and its impacts; patterns and their mirroring in bodies and environments; and as a complex association of affects - between mothers and daughters, various business interests (e.g. fossil fuels, cigarettes) and the domestic interior, political discourses and direct action. It is also important, that Kimbell's work (the toile and its positioning here, in this book) is simultaneously, but not unambiguously - and therefore neither exhausted in any of these tendencies nor totalizing of all of them - a pragmatic, speculative and critical act of design.

\section{Pataphysics}

A tendency to ambiguity is important for anticipation scholar Mihai Nadin (2010, p. 26), who - citing Stephen Kercel (2007) - writes that 'ambiguity is an observable feature of complexity', with the consequence that anticipation is nothing if not complex and ambiguous. Our final chapter works through complexity, ambiguity and anticipation through the work of philosophical prankster Alfred Jarry (1873-1907) and his intellectual contribution of 'Pataphysics. Author Derek Hales has been a leading thinker in this field for a number of years. In addition, Hales is also an important proponent of 'design fictions' (Hales, 2013) and their relation to 'speculative design'. Informed by all of these is Hales's innovation practice especially in relation to regional development and his disciplinary field of architecture. In this chapter, 'The anticipatory power of the objectile', Hales takes the reader through the paradoxical theory and practice of 'anticipatory plagiarism' as it is played out in the work of various architects, philosophers and mathematicians and in relation to 'Pataphysics. This is defined as the 'science of imaginary solutions, which symbolically attributes the properties of objects, described by their virtuality, to their lineaments' (Jarry, 
1965, p. 145); furthermore, 'pataphysics stands in the same relation to metaphysics as metaphysics does to physics. Taught philosophy by Henri Bergson and with an ability to shock the bourgeoisie - which renowned 'Pataphysician Andrew Hugill (2015, p. 3) aligns with a possible etymology of the term: épataphysique, with épater being 'to shock' in French and the omitted 'e' leading to the preceding apostrophe - Jarry is probably most well-known for his play Ubu Roi (1968). There are a number of lines to take from this definition by Jarry. Thinking 'lineaments' as 'contours' we have some notions of Riemannian curved space - a mathematics that was important and popular as the nineteenth became the twentieth century. With 'virtuality', a gesture to Bergson; and, with a science characterized as 'imaginary', we confront many of the concerns of the other chapters in this book. Hales also re-examines the concept of the 'objectile' (see also: Hales, 2015). For Hales, the concept of the 'objectile' as developed by Gilles Deleuze (1993) regards an object not in any entirety but as a voyaging, processing of matter, a matter-flow (Hales, 2015). It therefore serves as a powerful pataphysical act: a throwing-out or throwing-up of thingness. This is, of course, also an act of drawing down the future into the present, as if it were the cup of a huge catapult machine only to be released to hurtle off again, goodness knows where. Hales brings to bear on such an anticipatory modelling two further concepts worth comment: anticipatory plagiarism and architectural fictions. These necessarily intertwine, but for brevity we can say that anticipatory plagiarism is the present's plagiarizing of future work. While couched in utterly pataphysical terms, this is also as good a definition of anticipation as one could have. Architectural fictions, strange, speculative acts that are creating a present with the future in, today, that will offer a future that is therefore already plagiarized. Hales manages this in a form of creative theory writing that is as awe inspiring and joyfully playful as any pataphysical text.

\section{Mode}

To close, there is the chapter by us, Jamie Brassett and John O'Reilly, first published in French, in the journal Prospective et Stratégie (Brassett and O'Reilly, 2018b). The chapter presented here is an amended and expanded English version of that article. We thank the General Editor of Prospective et Stratégie for permission to publish this version here. Now titled '2078/1978. Anticipation and the Contemporary', this chapter brings to anticipation a philosophical examination of the concept of 'the contemporary (person)' by Giorgio Agamben (2008) - itself informed by Friedrich Nietzsche's (1997) development of the 'untimely'. Agamben positions the contemporary person in a space situated both inside and outside the present and is regarded by both philosophers as a positioning that demands courage. In so doing, the contemporary stance allows the contemporary person to create a new present as a consequence of this position providing a view on the present's darkest moments. If this needs courage, we argue, so does anticipation. For it, too, demands that we adopt a position inside and outside the present in order to allow the future in and thus to make 
it anew. Such a positioning is mirrored in some futures work; notably, Riel Miller's (2011) urge to adopt a 'scenaric stance', which also requires a move away from an epistemological situation (searching for meanings) towards an ontological one (thinking and practising beings and becomings). As we have discussed earlier in this introduction, the work of Roberto Poli (2010b, 2011, 2017) has also become important in developing anticipation studies in recent years. For Poli, an anticipatory stance requires a certain 'irrelevance', a step outside of current norms to be able to get a perspective on the future. This is exactly the same word as Agamben uses to characterize the contemporary: 'irrelevance'. We develop an argument that positions untimely, contemporary and anticipatory in proximity to each other. In doing this, we overturn some thoughts and practices that we do not have time to cultivate, eager as we are to keep focus upon our main topics of enquiry. Chief amongst these is Whitehead's conception of 'speculative' philosophy. While this practice/ concept has been prominent in recent years - Brassett (2016, p. 163) notes, among a variety of disciplines: 'speculative design' (also discussed by Hales and practised by Kimbell in this volume), 'speculative history', 'speculative realism' - a thorough investigation of the knot resulting from twining together Whitehead's speculative philosophy, anticipation studies and creative ontologies would be insightful future research.

\section{Immediate existence (whenever that may be)}

What each of these essays compose is a different way of styling the future (Brassett and O'Reilly, 2015) that has not already been predicted; with these styles generating atmosphere, as we noted above. Anticipation thought this way is a singular, creative and flourishing act; otherwise the future merely comes already prefabbed. Organization scholar Barbara Czarniawska writes in 'The Style and the Stylists of Organization Theory' (2005, p. 240):

we speak of 'texts lacking style' that can be best described as compilations of words and phrases rather than as 'the work on the words'. Style is the writer's awareness of being engaged in writing, incorporated into the text itself (as opposed to lack of such awareness, but also to self-reflective or meta-reflexive texts).

Anticipation that truly engages in the unknown-unknown needs to create a different language with which to translate the future: to style the future in a way for the present, as we anticipated a few years ago (Brassett and O'Reilly, 2015). The different styles of each chapter are also = literally, cognitively, fashionably - modes of anticipation, modes of anticipation as ontological transformation: Picturing; Runes; Hope; Rules; Stitching; Love; Emission; Pataphysics; Mode. As much as each chapter is a situated engagement with the concept and practices of anticipation, we hope the reader will register theses different modes of anticipation. Anticipation is the capacity of futures studies for opening up to 
the multiple modes of future becoming, beyond the corporate 'unreal estate of the future', to making futures that are creative, ethical and lovely.

The timelines of this book as an anticipated work in all our futures are drawn back to the knots of our meetings in presents now past. Or they form as separate strands of practice, highlighting a manifold of anticipations that have communicated sometimes strongly, other times not, and every place inbetween. This has been a fascinating process into and out of anticipation in thought and practice. George Orwell, in Nineteen Eighty-Four, tells us that ' $[\mathrm{t}]$ he best books are the books that tell you what you know already'; these books, like algorithms, have already predicted us. But life cannot be reduced to or represented by an algorithm (Nadin, 2011). If this is what the best is, then we are hoping that this book on anticipation will become one of the worst.

\section{Notes}

1 We should note that futures scholar, Marcus Bussey (2013,2017), engages with a philosophical focus very much in alignment with many of ours in this volume.

2 Futures and education scholar Keri Facer (2018) uses Whitehead's (1968, pp. 171-174) position on the future-focused role of the university to critique its neoliberalization (among other things) - thus bringing an important political aspect to play in issues around higher education and the future.

\section{References}

Agamben, G. (2008) 'What is the Contemporary?', in Agamben, G. (ed.), What is an Apparatus? and other Essays. Trans. D. Kishik and S. Pedatella. Stanford, CA: Stanford University Press, pp. 1-24.

Anderson, B. (2009) 'Affective Atmospheres', Emotion, Space and Society, 2, pp. 77-81.

Bala, A. (2006) The Dialogue of Civilizations in the Birth of Modern Science. New York, NY: Palgrave Macmillan.

Batman Begins (2005) Directed by C. Nolan. [Feature Film]. Burbank, CA: Warner Bros. Pictures.

Bloch, E. (2000) The Spirit of Utopia. Trans. A.A. Nassar. Stanford, CA: Stanford University Press.

Bloch, E. (1985) Philosophische Aufsätze zur objektiven Phantasie. Frankfurt am Main: Suhrkamp.

Bousbaci, R. (2008) “"Models of Man” in Design Thinking: The "Bounded Rationality" Episode,' Design Issues, 24(4), (Autumn), pp. 38-52.

Brassett, J. (2018) 'Creating Affective Social Design. An Ethical and Ontological Discussion', Cubic Journal, 1, Special Issue: 'Design Social', pp. 146-159.

Brassett, J. (2016) 'Speculative Machines and Technical Mentalities: A Philosophical Approach to Designing the Future', Digital Creativity, 27(2), pp. 163-176.

Brassett, J. (2015) 'Poised and Complex. The Becoming Each Other of Philosophy, Design and Innovation', in Marenko, B. and Brassett, J. (eds.), Deleuze and Design. 'Deleuze Connections' Series. Edinburgh: Edinburgh University Press, pp. 31-57.

Brassett, J. and O'Reilly, J. (2018a) 'Collisions, Design and The Swerve', in Vermaas, P. and Vial, S. (eds.), Advancements in Philosophy of Design. 'Design Research Foundations' Series. Cham, Switzerland: Springer, pp. 71-98. 
Brassett, J. and O'Reilly, J. (2018b) 'Retour à 2078: Réflexions sur l'anticipation et le contemporain', Revue de Prospective et Stratégie, 9, Édition Spéciale 'Voir Loin', (December), pp. 11-22.

Brassett, J. and O'Reilly, J. (2015) 'Styling the Future. A Philosophical Approach to Scenarios and Design', Futures, 34, 'Scenarios and Design' Special Issue, pp. 37-48.

Brown, T. (2009) Change by Design: How Design Thinking Transforms Organizations and Inspires Innovation. New York, NY: HarperCollins Publishers.

Bussey, M. (2017) 'Anticipatory Aesthetics: The Senses and the Body in Anticipatory Theory and Practice', in Poli, R. (ed.), Handbook of Anticipation. Cham, Switzerland: Springer International Publishing AG. doi:10.1007/978-3-319-31737-3_84-1.

Bussey, M. (2013) 'Foresight Work as Bridge Building: Poetry, Presence and Beyond', Journal of Futures Study, 17(4), pp. 103-116.

Celi, M. and Morrison, A. (2017) 'Anticipation and Design Inquiry', in Poli, R. (ed.), Handbook of Anticipation. Cham, Switzerland: Springer International Publishing AG. doi:10.1007/978-3-319-31737-3_49-1.

Chia, R. (1999) 'A "Rhizomic" Model of Organizational Change and Transformation: Perspective from a Metaphysics of Change', British Journal of Management, 10, pp. 209-227.

Czarniawska, B. (2005) 'The Styles and Stylists of Organization Theory', in Knudsen, C. and Tsoukas, H. (eds.), The Oxford Handbook of Organization Theory: Metatheoretical Perspectives. Oxford: Oxford University Press, pp. 237-261.

DeLanda, M. (1991) War in the Age of Intelligent Machines. New York, NY: Zone Books.

Deleuze, G. [1986] (1995) 'Breaking Things Open, Breaking Words Open', in Deleuze, G. (ed.), Negotiations 1972-1990. Trans. M. Joughin. New York, NY: Columbia University Press, pp. 83-93.

Deleuze, G. [1988] (1993) The Fold. Leibniz and The Baroque. Trans. T. Conley. London: The Athlone Press.

Deleuze, G. [1969] (1990a) The Logic of Sense. Trans. M. Lester with C. Stivale. Ed. C. Boundas. London: The Athlone Press.

Deleuze, G. [1968] (1990b) Expressionism in Philosophy: Spinoza. Trans. M. Joughin. New York, NY: Zone Books.

Deleuze, G. [1986] (1988) Foucault. Trans. S. Hand. London: The Athlone Press.

Deleuze, G. [1962] (1983) Nietzsche and Philosophy. Trans. H. Tomlinson. London: The Athlone Press.

Deleuze, G. and Guattari, F. [1991] (1994) What is Philosophy? Trans. G. Burchill and H. Tomlinson. London: Verso Books.

Deleuze, G. and Guattari, F. [1980] (1988) A Thousand Plateaus: Capitalism and Schizophrenia 2. Trans. B. Massumi. London: The Athlone Press.

Deleuze, G. and Guattari, F. [1972] (1984) Anti-CEdipus. Capitalism and Schizophrenia 1. Trans. R. Hurley, M. Seem, and H.R. Lane. London: The Athlone Press.

Dunne, A. and Raby, F. (2013) Speculative Everything. Design, Fiction and Social Dreaming. Cambridge, MA and London: The MIT Press.

Facer, K. (2018) 'The University as Engine for Anticipation: Stewardship, Modelling, Experimentation, and Critique in Public', in Poli, R. (ed.), Handbook of Anticipation. Cham, Switzerland: Springer International Publishing AG. doi:10.1007/978-3-319-31737-3_29-1.

Freedland, J. (2012) 'Eugenics: The Skeleton that Rattles Loudest in the Left's Closet', The Guardian, 17 February. Available at: https://www.theguardian.com/commentisfree/201 2/feb/17/eugenics-skeleton-rattles-loudest-closet-left (Accessed: 17 June 2020). 
Goodwin, N. (2014) 'The Human Element in the New Economics: A 60-Year Refresh for Economic Thinking and Teaching', Real-world Economics Review, 68, (August), pp. 98-118.

Hales, D. (2015) 'Redesigning the Objectile', in Marenko, B. and Brassett, J. (eds.), Deleuze and Design. 'Deleuze Connections' Series. Edinburgh: Edinburgh University Press, pp. 139-172.

Heidegger, M. [1915] (2007) 'The Concept of Time in the Science of History', in Kisiel, T. and Sheehan, T. (eds.), Becoming Heidegger: On the Trail of His Early Occasional Writings, 1910-1927. Evanston, IL: Northwestern University Press, pp. 61-72.

Hernes, T. (2014) A Process Theory of Organization. Oxford: Oxford University Press.

Hugill, A. (2015) Pataphysics: A Useless Guide. Cambridge, MA and London: MIT Press.

Huppatz, D.J. (2015) 'Revisiting Herbert Simon's “Science of Design”, Design Issues, 31(2), (Spring), pp. 29-40.

Jarry, A. (1968) The Ubu Plays. Trans. C. Connolly and S. Watson Taylor. London: Methuen.

Jarry, A. [1911] (1965) Selected Works of Alfred Jarry. Trans. R. Shattuck and S. Watson Taylor. London: Methuen.

Julier, G. (2017) Economies of Design. London: Sage.

Kay, J. (2013) 'Circular Thinking', RSA Journal, 159(5556), pp. 10-15.

Kercel, S. (2007) 'Entailment of Ambiguity', Chemistry and Biodiversity, 4(10), pp. 2369-2385.

Lambert, R. and Flood, R. (2018) Undertaking Design-Intensive Innovation: A Literature Review. London: The Design Council.

Latour, B. (2008) 'A Cautious Prometheus? A Few Steps Toward a Philosophy of Design (with Special Attention to Peter Sloterdijk)', in Hackney, F., Glynne, J., and Minton, V. (eds.), Networks of Design. Proceedings of the International Conference of the Design History Society. Boca Raton, FL: Universal-Publishers, pp. 2-10.

Lloyd Morgan, C. (1927) Emergent Evolution. The Gifford Lectures Delivered in the University of St. Andrews in the Year 1922. 2nd edn. London: Williams and Norgate.

Lucretius [55BCE] (2007) The Nature of Things. Trans. A.E. Stallings. London: Penguin Books.

Marenko, B. (2015) 'When Making Becomes Divination: Uncertainty and Contingency in Computational Glitch-Events', Design Studies, 41(A), (November), pp. 110-125.

Marenko, B. (2014) 'Neo-Animism and Design. A New Paradigm in Object Theory', Design and Culture, 6(2), 'Design, Thing Theory and the Lives of Objects' Special Issue, pp. 219-242.

Martin, R. (2009) The Design of Business: Why Design Thinking is the Next Competitive Advantage. Boston, MA: Harvard Business Press.

Marx, K. [1856] (1978) 'Speech at the Anniversary of the People's Paper', in Tucker, R.C. (ed.), The Marx-Engels Reader, 2nd edn. London: Norton, pp. 577-578.

Massumi, B. (2010) 'The Future Birth of the Affective Fact: The Political Ontology of Threat', in Gregg, M. and Seigworth, G.J. (eds.), The Affect Theory Reader. Durham, NC: Duke University Press.

Miller, R. (2011) 'Being without Existing: The Futures Community at a Turning Point? A Comment on Jay Ogilvy's "Facing the Fold", Foresight, 13(4), pp. 22-34.

Miller, W. (2011) The Darker Side of Western Modernity: Global Futures, Decolonial Options. Durham, NC: Duke University Press.

Nadin, M. (2011) 'The Anticipatory Profile. An Attempt to Describe Anticipation as Process', International Journal of General Systems. doi:10.1080/03081079.2011.622093. 


\section{Jamie Brassett and John O'Reilly}

Nadin, M. (2010) 'Anticipation and Dynamics: Rosen's Anticipation in the Perspective of Time', International Journal of General Systems, 39(1), pp. 3-33.

Napoleon Dynamite (2004) Directed by J. Hess. [Feature Film]. Los Angeles, CA: Fox Searchlight Pictures.

Nietzsche, F. (1997) Untimely Meditations. Ed. D. Breazeale. Trans. R.J. Hollingdale. Cambridge: Cambridge University Press.

Orwell, G. [1949] (2000) Nineteen Eighty-Four. London: Penguin Books Ltd.

Poli, R. (2017) Introduction to Anticipation Studies. 'Anticipation Science' Series, vol. 1. Berlin: Springer.

Poli, R. (2011) 'Steps Toward an Explicit Ontology of the Future', Journal of Futures Studies, 16(1), pp. 67-78.

Poli, R. (2010a) 'The Many Aspects of Anticipation', Foresight, 12(3), pp. 7-17.

Poli, R. (2010b) 'An Introduction to the Ontology of Anticipation', Futures, 42(7), pp. 769-776.

Poli, R. and Seibt, J. (eds.) (2010) Theory and Application of Ontology: Philosophical Perspectives, vol. 1. Dordrecht: Springer Netherlands.

Renwick, C. (2019) 'Movement, Space and Social Mobility in Early and Mid-TwentiethCentury Britain', Cultural and Social History, 16(1), pp. 13-28.

Rosen, R. [1985] (2012) Anticipatory Systems: Philosophical, Mathematical and Methodological Foundations, 2nd edn. New York, NY: Springer.

Rosen, R. (2000) Essays on Life Itself. New York, NY and Chichester, W. Sussex: Columbia University Press.

Rosen, R. (1991) Life Itself. A Comprehensive Inquiry Into the Nature, Origin, and Fabrication of Life. Complexity in Ecological Systems. Series. New York, NY and Chichester, W. Sussex: Columbia University Press.

Serres, M. (1982) 'On the Origin of Language: Biology, Information Theory, and Thermodynamics', in Serres, M. (ed.), Hermes. Literature, Science, Philosophy. Baltimore, MD: Johns Hopkins University Press, pp. 71-73.

Serres, M. (1977) La Naissance de la physique dans le texte de Lucrèce. Fleuves et turbulences. Collection: Critique. Paris: Les Editions de Minuit.

Simon, H. (1988) 'The Science of Design: Creating the Artificial', Design Issues, 4(1/2), Special Issue: 'Designing the Immaterial Society', pp. 67-82.

Simondon, G. [1964/1989] (2013) L'individuation à la lumière des notions de forme et d'information. Paris: Éditions Jérôme Million.

Spinoza, B. de [1677] (1996) Ethics. Trans. E. Curley. London: Penguin Classics

Stengers, I. [2002] (2011) Thinking with Whitehead. A Free and Wild Creation of Concepts. Trans. M. Chase. Boston, MA: Harvard University Press.

Stengers, I. (2008) 'A Constructivist Reading of Process and Reality', Theory, Culture and Society, 25(4), pp. 91-110.

Stengers, I. (2005) 'Deleuze and Guattari's Last Enigmatic Message', Angelaki, 10(2), pp. 151-167.

Stengers, I. (1997) Cosmopolitiques. Tome 6. La Vie et l'Artifice: visages de l'émergence. Paris: Éditions La Découverte.

The Dark Knight Rises (2012) Directed by C. Nolan. [Feature Film]. Burbank, CA: Warner Bros. Pictures.

Tsoukas, H. (1998) 'Chaos, Complexity, and Organization Theory', Organization, 5(3), pp. 291-313.

Tsoukas, H. and Chia, R. (2002) 'On Organizational Becoming: Rethinking Organizational Change’, Organization Science, 13(2), pp. 567-582. 
Tushman, M.L. and O'Reilly III, C.A. (1996) 'The Ambidextrous Organization: Managing Evolutionary and Revolutionary Change', California Management Review, 38, pp. 1-23.

Verganti, R. (2009) Design Driven Innovation: Changing the Rules of Competition by Radically Innovating What Things Mean. Boston, MA: Harvard University Press.

Whitehead, A.N. [1927-28] (1978) Process and Reality. An Essay in Cosmology, Corrected Edition. Eds. D.R. Griffin and D.W. Sherburne. New York, NY: The Free Press.

Whitehead, A.N. [1938] (1968) Modes of Thought. New York, NY: The Free Press.

Whitehead, A.N. [1925] (1967a) Science and the Modern World. New York, NY: The Free Press.

Whitehead, A.N. [1933] (1967b) Adventures of Ideas. New York, NY: The Free Press.

Yelavich, S. and Adams, B. (eds.) (2014) Design as Future-Making. London and New York, NY: Bloomsbury. 